DOI: http://dx.doi.org/10.22483/2177-5796.2017v19n3p631-650

\title{
Onde estava a chave? Relatos tardios (e quase perdidos) de conversas cotidianas em uma escola na floresta
}

\author{
Rodrigo Barchi
}

Resumo: A Escola Bosque do Amapá, Módulo Regional do Bailique, foi inaugurada em 1998, com a intenção de promover um ensino que buscasse na floresta e nos saberes da população local, os conhecimentos que construíssem o currículo e as práticas pedagógicas da escola, de forma a fortalecer a autonomia da comunidade e desenvolver economicamente a região sem a necessidade de estabelecer uma relação predatória com o meio ambiente. Durante minha estadia na Escola Bosque no ano de 2001, estabeleci uma série de conversas cotidianas com seus professores e professoras, especialmente aqueles(as) que não eram originários do Bailique, e esse texto constrói uma série de narrativas ficcionais, mas baseadas em situações reais, a partir dessas conversas e relatos, dando destaque às suas impressões, esperanças, desilusões, saudades, alegrias, tristezas e posicionamentos políticos, sociais e culturais.

Palavras-chave: Escola Bosque do Amapá. Bailique. Cotidiano escolar. Conversas cotidianas. Educação ambiental.

\section{Where was the key? Late stories (and almost lost) of daily talks in a school in the forest}

\begin{abstract}
The School "Bosque do Amapá", Regional Module of Bailique was open in 1998 in order to promote an education that searched for knowledge in the forest and in the local population to build the school curriculum and pedagogical practices in a way to strengthen the community autonomy and economically develop the region without the need to establish a predatory relationship with the environment. During my stay at Bosque School in 2001, I established a series of daily talks with teachers, especially the ones that were not from Bailique. And this text builds a series of fictional narratives, but based on real situations from these talks and stories focused on their impressions, hopes, disillusions, homesickness, happiness, sadness and political, social and cultural position.
\end{abstract}

Keywords: The school "Bosque do Amapá". Bailique. School life. Daily talks. Environmental education. 


\section{Por que só agora?}

Após estar confinado durante doze horas no barco de passageiros que liga Macapá até o Arquipélago do Bailique, a visão que tive ao chegar à Vila Progresso e à Escola Bosque do Bailique foi extremamente deslumbrante. Aliás, toda a paisagem do trajeto é magnífica: o rio, a floresta, as aves, os insetos e as eventuais comunidades ribeirinhas, quando não as palafitas isoladas.

À noite, a lua cheia reinava soberana e inconteste. Apesar do cheiro de óleo diesel e a fumaça tomarem conta de todo o ambiente do barco, o céu azul turquesa durante o dia, e multicolorido, com os tons vermelho, amarelo e rosa ao final da tarde, impediram qualquer sensação de incômodo.

Fui pela primeira vez ao Bailique, em novembro de 2000, e participei da Terceira Semana de Cultura e Ciência da Escola Bosque do Amapá, onde foram expostos para a comunidade, representantes do governo estadual, cientistas, estudantes e até alguns turistas, os trabalhos realizados pela "Bosque" (como era geralmente chamada pelas pessoas que trabalham e estudam ali), juntamente com a realização de gincanas, minicursos e apresentações teatrais e musicais.

Foi nessa viagem ao Bailique que conheci Paulo Roberto Sposito, o Palhaço Magnólio, um dos mais notáveis educadores ambientais brasileiros, cujo trabalho com o Projeto Saúde e Alegria e o Gran Circo Mocorongo, desde o final dos anos 80, foi responsável por levar conhecimento e conscientização sobre saúde e meio ambiente à centenas de populações ribeirinhas na região amazônica. Ele trabalhava junto com Marcos Reigota e Nilson Moulin como consultor em educação para o Governo do Estado do Amapá, e seu passamento ao final do ano de 2016 foi uma das razões pelas quais estou trazendo este texto a público.

Eu tinha pouco mais de 20 anos naquele momento, e aprendi com ele, especialmente, a importância de não perder nem a seriedade, nem a alegria no trabalhado educativo, sendo necessário que a educação saísse de sua alcunha extremamente formal para que pudesse conseguir o estabelecimento de um diálogo aberto, franco e construtivo com os educandos e educandas. O Magnólio me acompanhou na maior parte das atividades que realizei no Amapá em minha primeira estadia, e influenciou muito as leituras minuciosas que eu faria posteriormente sobre a relação entre educação e cultura em Paulo Freire. 
Esse texto, portanto, é em primeiro lugar, uma homenagem póstuma a esse magnífico educador, ambientalista e militante político e social que foi Paulo Roberto Sposito, o palhaço Magnólio.

Na segunda vez que estive no Bailique, em agosto de 2001, fui acompanhar o início do semestre letivo, e pude observar um pouco do cotidiano não extraordinário - como foi da primeira vez, em que fui durante um evento - dos professores, funcionários e estudantes da escola. Eu era um aluno de graduação em Geografia na Universidade de Sorocaba, e havia conseguido, a partir da ajuda de Marcos Reigota e sua presença na consultoria em Educação Ambiental do Estado do Amapá naquele momento, uma estadia, que considero quase que um intercâmbio, e me possibilitou estar durante várias semanas no Estado do Amapá.

Fui acompanhar os trabalhos do Programa de Desenvolvimento Sustentável do Amapá, ou PDSA (MOULIN, 2000; LEONELLI, 2000), o qual, entre os anos de 1995 e 2002, buscou implantar em todo o Estado, as orientações da Agenda 21. Esse texto é também um relato das impressões e conversas que tive durante minha estadia, como estudante "intercambista", no Estado do Amapá durante o PDSA.

Trago, em forma de narrativas ficcionais (REIGOTA, 1999), alguns discursos de professores e professoras com quem conversei e convivi durante minha segunda estadia na "Bosque". Todas e todos tiveram seus nomes alterados, principalmente por causa da esporadicidade com a qual as conversas e situações ocorreram, além de manter o anonimato, mesmo tendo tanto tempo passado, e provavelmente mais nenhum deles(as) estar trabalhando por lá. Após a viagem, não consegui manter o contato com mais nenhum deles, e não consegui nem encontrá-los(as) nas redes sociais, para ter notícias e/ou atualizações de seus trabalhos.

Este texto estava guardado há cerca de quinze anos, e resolvi trazê-lo à tona como forma de resgate das experiências e das posições sociais, políticas, pedagógicas e ecológicas de alguns educadores que estavam naquele momento exercendo o trabalho educativo naquela escola. Baseado principalmente nos trabalhos de Mary Jane Paris Spink (SPINK, 1999), Peter Spink (SPINK, 2008) e Vera Menegon (MENEGON, 1999), considero que os fragmentos que aqui apresento a partir das conversas que tive com os professores e professoras da escola, mesmo que tardios, são de vital importância para apresentar um pouco dos temores, esperanças e dificuldades do trabalho no cotidiano escolar nos extremos do Brasil. 


\section{A escola na floresta}

O Bailique é um arquipélago marítimo-fluvial, e seu território faz parte dos limites do município de Macapá, sendo um distrito da capital amapaense. Hoje são pouco mais de sete mil habitantes, distribuídos em mais de 40 comunidades espalhadas pelas oito ilhas: Bailique, Franco, Brigue, Faustino, Curuá, Parazinho, Meio e Marinheiro. A maior comunidade do Bailique é a Vila Progresso, ao lado da qual foi construída a Escola Bosque do Bailique, em 1998, sendo um dos maiores expoentes do PDSA (AMAPÁ, 1999; LEONELLI, 2000; MOULIN, 2000).

Seu método socioambiental foi elaborado pelos idealizadores da Escola Bosque, José Mariano Klautau de Araújo e Dula Maria Bento de Lima, onde a história, a geografia, a tradição e os conhecimentos locais serviriam, constantemente, para a construção do currículo e da metodologia de ensino (AMAPÁ, 1997a, 1997b, 1997c, 1997d, 1997e, 1997f, 1997g). Todas as madeiras utilizadas para a construção da escola foram retiradas do próprio Bailique (AMAPÁ, 2000), assim como a maior parte da mão de obra.

A mudança na governança do Estado fez com que toda a proposta fosse praticamente abandonada, fazendo com que o currículo escolar se submetesse à centralidade das propostas promovidas Secretaria de Educação do Estado, prejudicando o projeto inicial que buscava a construção de uma autonomia curricular e pedagógica para a escola. Enquanto que a reportagem de Roberta Bencini (1998) enaltecia o trabalho e os prêmios ganhos internacionalmente pela escola, atualmente lamenta-se a falta de continuidade do trabalho, como relatado na reportagem realizada pela revista Nova Escola, em abril de 2015:

No Bailique, o cenário anterior ao projeto voltou. Habitantes abandonam as ilhas. Saberes tradicionais, como o de carpintaria naval, são esquecidos. Pouco a pouco, a falta de manutenção e a força da natureza levam adiante a melancólica tarefa de apagar os vestígios do projeto que poderia ter transformado a Educação da região. A arquitetura original, com coberturas de palha à moda das ocas waiãpi, deu lugar a telhados de amianto, incompatíveis com o clima quente e úmido. A cena de alunos sentados em carteiras enfileiradas dentro de salas abafadas substituiu o contato direto com a natureza de que fala a reportagem de 1998 em NOVA ESCOLA. Não acontecem as lições planejadas embaixo das árvores ou na horta da instituição - hoje vazia - e à beira do rio. $\mathrm{O}$ auditório com infraestrutura completa, à disposição para eventos que receberiam pesquisadores, está subaproveitado. E a louça fabricada especialmente para os hóspedes do Hotel Escola Bosque, ornamentada com o logotipo da instituição, hoje é usada apenas nas raras festas da própria escola. Por lá, não há muito o que comemorar (RATIER; SALLA; SEMIS, 2015). 
Quando estive por lá em 2001, a Escola Bosque desenvolvia o trabalho ainda de acordo com a proposta inicial, mas, como exponho adiante, já havia alguns problemas, que seriam intensificados com a ruptura do programa e, consequentemente, o fim da autonomia pedagógica da escola nos anos seguintes. No entanto, naquele momento, havia, aparentemente, o zelo do Governo do Estado e da comunidade, que depositavam na escola a esperança da possibilidade de evitar o êxodo de jovens em direção à Macapá ou outros estados. Além de fortalecer a economia local, sem a necessidade de estabelecer uma dinâmica predatória para tal empreitada.

Fui acompanhar o início das aulas do segundo semestre letivo do ano de 2001. Obviamente que fiquei espantado, estarrecido (num bom sentido) e admirado com o trabalho realizado na escola pela comunidade, cujas principais atividades estavam ligadas ao extrativismo vegetal, à pesca, à engenharia naval, à produção de fitoterápicos e ervas medicinais, e às pequenas roças e criações de animais. Além, claro, de estar constantemente maravilhado pelo esplendor da floresta e do rio.

Mas também, naquele momento, a primeira vista considerei a Escola Bosque do Bailique um tremendo "elefante-branco", devido à discrepância entre o espaço ocupado pela escola e por sua arquitetura, que se sobressaíam demasiadamente ao espaço ocupado pelas casas, cujos formatos, em sua grande maioria, estavam mais próximos aos casebres encontrados nos bairros mais pobres de Macapá naquela época, que beiravam o Igarapé das Mulheres e o Igarapé das Pedrinhas. No entanto, aquela sensação de disparidade se dissiparia exatamente no momento em que entrei nas salas de aula da escola, pequenas e quentes.

A Escola Bosque do Bailique foi construída com o apoio da UNICEF (AMAPÁ, 2000), e seria a primeira de cinco a ser implantadas no Estado do Amapá. Na verdade, a primeira a ser inaugurada foi a Escola Bosque da Ilha de Santana, a qual nunca entrou em real funcionamento, e que hoje tem sua estrutura completamente deteriorada e em ruínas, sendo ainda alvo de enclaves judiciais.

Entre os anos de 1998 e 2002, foi crescente o fluxo de viajantes para a região, como políticos, jornalistas, cientistas, professores e, assim como eu naquele momento, estudantes intercambistas, que enfrentavam muitas vezes a grande maresia do rio Amazonas para pesquisar, trabalhar, ou simplesmente passear. Geralmente são pequenos barcos de trinta metros de extensão por menos de quatro de largura, o qual, inacreditavelmente (para alguém que até então nunca 
havia enfrentado 13 horas dentro de uma embarcação daquelas), faz uma viagem de cento e oitenta quilômetros, distância que separa Macapá do Bailique.

Minha rede havia ficado ao lado da pilastra do barco, bem perto ao motor. Se eu não tive problemas de enjoo devido ao "estômago forte", não posso dizer a mesma coisa do meu sono, impossibilitado pelo barulho do motor, pela fumaça do óleo queimando e pelas pancadas que a rede dava na pilastra do barco, devido ao ininterrupto balanço. Na manhã seguinte, meu braço estava cheio de hematomas. No entanto, a imagem da floresta, do céu durante o dia, da lua cheia à noite e a própria Escola Bosque fazem com que eu ainda lembre com enorme nostalgia toda essa situação.

Para sustentar o grande fluxo de viajantes naquele período, estava sendo erguido, a meio caminho entre a Escola Bosque e a Vila Progresso, o Hotel da Escola Bosque, que possuía uma arquitetura semelhante, e os mesmos princípios de utilização de mão de obra e material da região para sua construção. Além disso, naquele momento estavam sendo concluídos mais dois módulos da escola para juntar-se aos outros seis em funcionamento.

\section{Das facas às bazucas}

Ao caminhar com o Leonardo pelo hotel em construção, ele me mostrava onde seriam os quartos, o restaurante, os salões de reuniões e conferências, e me explicava os porquês de uma obra tão grande no meio da floresta, justificando os efeitos que podiam causar no ambiente da região, e todos os cuidados que haviam sido tomados para que os impactos não fossem tão significativos.

A entrada do hotel estava distante aproximadamente uns cinquenta metros da margem do rio, e se adentrava na floresta cerca de quatrocentos metros, os quais eu e o Leonardo tivemos que caminhar sobre as estruturas de madeira que eram mais finas que a largura de nossos pés. Chegamos ao fundo do hotel - depois de eu quase ter caído em um igarapé após perder o equilíbrio - onde havia uma grande clareira aberta para a construção do último módulo.

O Leonardo foi diretor da Escola Bosque desde sua inauguração, e eu havia o conhecido na primeira vez em que estive lá. Ele me forneceu toda a estrutura necessária para o meu retorno ao Bailique, além de ter permitido minha livre circulação e integração à escola. 
Para essa segunda estadia no Bailique, ao sair de Macapá, iríamos tomar o barco "Albatroz", que sairia da doca do Perpétuo Socorro às quinze horas do último sábado do mês de julho, quando muitas pessoas estariam regressando ao arquipélago devido ao início das aulas. No entanto, aquele barco começou a encher de gente, e as histórias e notícias de barcos superlotados que afundavam nos rios amazônicos começaram a povoar minha cabeça...

Eu e o Leonardo resolvemos esperar o barco da madrugada, o "Micleice", que partiria às três da manhã, levando os professores da "Bosque". O Albatroz, com capacidade para transportar quarenta passageiros e redes, estava já carregando mais de uma centena de pessoas, fazendo com que eu desistisse, e que também a Capitania dos Portos impedisse o barco de continuar a viagem, dez minutos depois que ele havia partido do porto.

Formado em Agronomia pela Universidade Federal da Bahia, Leonardo aceitou o convite de dirigir a Escola Bosque do Bailique um pouco depois de ter abandonado o curso de Mestrado em Educação e Agronomia. Durante uma de nossas conversas no barco, afirmava enfaticamente que, ao contrário do que ocorria (e ainda ocorre) em muitas escolas públicas em todo o Brasil (inclusive em Macapá), ele não era obrigado a usar de um autoritarismo no qual muitos diretores e diretoras baseiam seu trabalho para manter as escolas "em ordem".

Mas às vezes, era obrigado a tomar medidas drásticas, para não permitir que algumas situações degringolassem para a violência e a barbárie. Foi o caso do menino que havia esfaqueado o colega durante a festa junina de 2001, como consequência de uma briga por namorada, sendo assim, o primeiro aluno a ser expulso da escola.

Esse foi um dos motivos pelos quais o Leonardo, no segundo dia de aula após as férias de julho, convocou uma reunião em todos os períodos, um pouco antes do intervalo, com todos os alunos e professores presentes. Conversou com os alunos de um modo calmo e tranquilo, sem nenhum momento se alterar ou levantar a voz, mas com uma convicção e seriedade que fez com que todos que estivessem ali ouvissem com extrema atenção, nem se manifestassem durante sua arguição.

Leonardo falou bastante sobre a questão da violência na escola, e anunciou que estava sendo cancelado, por um bom tempo, o uso de talheres de metal pelos alunos, que estavam os levando embora e transformando em armas: "Em pouco tempo, vocês vão acabar trazendo metralhadoras Uzi, canhões, mísseis balísticos...", dizia ele, tentando quebrar o gelo e 
descontrair um pouco mais a reunião, arrancando diversas gargalhadas dos presentes. Anunciou ainda a criação de uma caixinha de denúncias anônimas contra a violência na escola.

Entre outros, anunciou a obrigatoriedade do uniforme, para garantir a segurança dos alunos e alunas, e também abordou a questão do serviço militar para os jovens que completariam dezoito anos, pois estes teriam que ficar em Macapá por alguns dias, e ficariam isentos das faltas.

Mas de todos os tópicos abordados pelo Leonardo nas reuniões, houve um que considerei extremamente agravante. Quando foi inaugurada, a Escola Bosque tinha previsto que a merenda seria regionalizada e servida, além dos intervalos entre as aulas, também durante a hora do almoço. Além disso, as refeições seriam fartas, fornecendo todas as calorias e nutrientes necessários para os alunos e alunas: arroz, feijão, carne, açaí, farinha de mandioca, salada e os sucos típicos da região.

De seis mil reais disponibilizados mensalmente para a merenda na época de inauguração, a escola passou a receber três mil reais e, a partir daquele momento - agosto de 2001 - a verba não passaria dos oitocentos reais. Explicava ele que a falta de recursos era geral no Estado, e não havia previsão de mudança. A crise econômica brasileira de 1999 ainda fazia sentir seus efeitos, e a merenda no Bailique também estava sendo afetada. Das refeições que eram antes servidas, os lanches passaram a ser constituídos, na grande maioria das vezes, de bolachas e sucos.

Além da função de diretor, Leonardo trabalhava junto à coordenação da escola, na orientação aos professores e professoras, e tentava resolver algumas questões estruturais, como a situação do fornecimento de água e energia elétrica, que conforme eram ajustados na escola, também modificavam toda a rede de distribuição para as cento e cinquenta casas da Vila Progresso.

\section{Rádios e farmácias}

Aliás, cento e cinquenta casas foi o número que me deu o Sabá, quem conheci durante a reunião da manhã. Enquanto o Leonardo falava, ele arrecadava assinaturas para que a Rádio Comunitária do Bailique fosse reaberta, já que havia sido fechada pela Agência Nacional de Telecomunicações por supostas irregularidades e ilegalidade.

O Sabá era um dos moradores mais ativos da região, nascido no próprio Bailique, e era diretor da Rádio Comunitária local, a qual prestava serviços e dava diversas informações aos 
bailiquenses. Mas devido à realização do "Bailique Verão" - uma série de eventos realizados pela Prefeitura de Macapá durante o verão amapaense, que incluía shows, concursos, gincanas e outras atividades - no qual foi a Rádio Comunitária a responsável pela animação, algum morador descontente e incomodado com o barulho do evento, contatou a Anatel para denunciar as virtuais irregularidades.

Ele também me contou um pouco da história da região do Bailique, e das suas comunidades com mais de cem anos, que era o caso do Buritizal - a primeira a ser registrada oficialmente - e também a do Franquinho.

Ao contrário dos irmãos, que lidavam com a construção naval, ele trabalhava na construção civil, e mostrava muita preocupação com o crescimento de serviço que tinha pela frente, pois cada vez mais pessoas estavam se alojando na Vila Progresso, e temia que essa situação pudesse prejudicar o equilíbrio ecológico na região.

E, apesar da inauguração da Escola Bosque, em 1998, com inúmeras famílias voltando ao Bailique na época, e devido à própria escola desenvolver naquele momento os cursos de carpintaria naval, o Sabá comentava que havia cada vez menos pessoas trabalhando na área, pois os mais jovens não estavam se interessando pelo ramo, o que foi confirmado por duas funcionárias da escola que estavam ao nosso lado durante a conversa.

Quem havia me indicado para conversar com o Sabá para saber um pouco mais sobre o Bailique havia sido o Anderson. Formado em Biologia na cidade do Rio de Janeiro, trabalhou em alguns lugares pelo Brasil antes de chegar ao Amapá e ao Bailique. Solteiro, assim como era a maioria dos professores da Escola Bosque - ao contrário das professoras, que eram na maioria casadas - não se incomodava muito em ter que ficar isolado durante vinte e cinco dias por mês na região do Bailique.

Ao contrário, estava encantado pela floresta, o que se notava cada vez em que um animal surgia perto da escola, ou avistávamos uma planta diferente em nossas caminhadas pelas palafitas que ligavam os módulos da escola. Gritava em voz alta, para todos ouvirem: "Isso é Amazônia!", e sempre repetia sobre a grande alegria em estar na Escola Bosque. Era professor e também trabalhava como projetista de alguns empreendimentos, como o Projeto "Farmácia da Terra" que desenvolvia ervas medicinais - e também o canteiro de mudas de árvores nativas.

Conheci o Anderson na Biblioteca da Secretaria do Meio Ambiente do Amapá, em Macapá, enquanto eu estava agendando, uns dias antes de minha ida ao Bailique, uma visita 
à Escola Família Agrícola do Carvão (REIGOTA, 2000), na cidade de Mazagão Velho, a qual, apesar da preocupação com o meio ambiente desde sua fundação, tem uma proposta pedagógica bem diferente da Escola Bosque, desde a construção do seu currículo, sua metodologia de trabalho - que adotou a Pedagogia da Alternância - passando pela arquitetura, pela captação de recursos e o cotidiano dos professores e professoras.

Assim como outros professores que tinham residência em Macapá, mas passavam vinte e cinco dias por mês na "Bosque", o Anderson via o seu vínculo com o Bailique como "passageiro", alvejava outros voos e fazia de sua estadia ali apenas uma experiência, já que, no próprio projeto original da escola, a preferência era contar apenas com professores e professoras da região em seu corpo docente.

\section{A guia}

Passageira também era a estadia da Daniela. Formada em magistério, fazia quase onze meses que estava trabalhando no Bailique, ministrando aulas de primeira a quarta série do Ensino Básico. A Daniela foi a primeira professora que conheci durante a viagem, enquanto ainda estávamos esperando a partida do barco, na Doquinha do Perpétuo Socorro, em Macapá. Ela me contava sobre sua vontade de fazer o curso de Pedagogia, em Sobral, no Ceará, mas estava tentando convencer alguém a ir junto, pois não queria ir sozinha.

A Daniela foi, em muitos momentos, minha principal guia no Bailique, especialmente quando caminhávamos pela Vila Progresso. Ela conhecia quase todas as alunas e alunos da escola, e ao andar em sua companhia pela comunidade, me sentia andando com uma celebridade, devido à sua grande popularidade, inclusive entre não alunos(as) da escola. Isso sem contar os inúmeros olhares de espanto em minha direção, pois quem seria aquele estranho rapaz de cabelos longos e barbas caminhando ao lado da professora...

Talvez por ser uma pessoa não originária da comunidade, mas estando já há um bom tempo por lá, ela naquele momento era a professora ideal para me contar as impressões "estrangeiras" sobre a Escola Bosque e o Bailique. Desde largar a família em Macapá, aos dezoito anos, logo após ter completado o magistério; as saudades dos parentes e dos amigos de infância e juventude; dormir em um alojamento no meio da mata ao lado de pessoas até então desconhecidas e a partir disso conviver com elas, além do acolhimento da comunidade. 
A Daniela havia me apresentado dezenas de pessoas, mas duas delas foram especialmente marcantes, e quero fazer o devido registro aqui.

Em primeiro lugar, sua amiga Jéssica, com quem se formou e também ministra aulas no Ensino Básico da "Bosque". Seu pai era considerado uma das pessoas mais importantes da história recente da Vila Progresso e de todo o Bailique, devido ao seu ativismo pela melhoria das condições da comunidade, cuja única escola na vila tem seu nome: "Cláudio Luis Santos Barbosa". Em sua casa, quase no fim da vila - a uma distância de quase três quilômetros da Escola Bosque - quase todos os cômodos estava ocupados pelos livros de Filosofia e Ciências Humanas do irmão, também professor da Escola Bosque - mas que não estava no Bailique durante minha estadia - e pelas inúmeras peças artesanais que ela fazia com penas, conchas, sementes, folhas e qualquer outro tipo de material que pudesse achar na floresta.

E em segundo lugar, sua tia Luciana, uma das moradoras mais antigas do Bailique, Dona Luciana nos contou que, entre outras coisas, havia aprendido a ler e escrever com os pais, já que na época de sua infância não havia tantas escolas no Bailique, e que conhecia o Arquipélago quase inteiro, pois viajava com o marido quando este fazia grandes trajetos. Após a morte dele, Dona Luciana não quis mais sair muito de casa, tanto que ainda não conhecia a Escola Bosque.

Por temer que seus alunos começassem prematuramente sua vida sexual, pois, assim como em outros lugares, no Bailique já havia muitas meninas sendo mães aos onze e doze anos, Daniela me contou que muitas vezes sentia-se "careta" diante de seus alunos e alunas. Isso porque geralmente era surpreendida em sala de aula com perguntas e comentários sobre os quais ela não esperava que fossem feitas por crianças daquela idade, entre sete e dez anos, e que tinha que fazer um grande esforço para não se aprofundar demais no assunto, mas também não deixálos sem as informações necessárias.

Eu lhe disse que iria sentir-se realmente "careta" com as abordagens dos alunos de quinta à oitava série do Ensino Fundamental, faixa etária com a qual eu trabalhava naquele momento como professor eventual em uma escola pública de Sorocaba. Expliquei que, principalmente com os professores jovens, como eu era naquele momento, as abordagens iam desde cartas de alunas e alunos apaixonadas pelos(as) docentes, passando por pedidos de ajuda para tentar ficar/namorar com determinado alguém, dúvidas sobre questões amorosas e ou sexuais, situações de violência doméstica, entre outras ocorrências do gênero. 
Ainda trocamos algumas experiências pedagógicas (apesar de sermos jovens docentes com pouco tempo de trabalho), e conversamos, entre outros assuntos, sobre ecologia e racismos. Enquanto eu ouvia sobre alguns casos que ela me contava sobre o preconceito que muitos colegas homossexuais sofriam em Macapá, ela ouvia abismada sobre alguns encontros desagradáveis que, na época, eu e alguns amigos punks e headbangers havíamos tido com neonazistas.

\section{Pensamento e indolência}

Enquanto a Daniela afirmava que se preocupava com cada palavra que dizia aos alunos e alunas, o Maurício não se intimidava em passar para sua turma uma entrevista do cartunista Ziraldo, o qual estava tão irritado com a situação brasileira na época do governo FHC, que não hesitou em soltar alguns bons palavrões. O Maurício, para reproduzir toda a raiva e indignação do cartunista, não pensou duas vezes em repetir suas palavras integralmente, enquanto lia a entrevista.

Formado em Letras pela Universidade Federal do Amapá, ele lecionava Literatura para classes do Ensino Médio e, em suas aulas, usava as mais diversas obras de autores(as) brasileiros(as) para explicar a situação na qual se encontrava o Brasil e o mundo.

Conversávamos, nos períodos entre aulas, sobre diversos assuntos, como o seu ecletismo - e o meu radicalismo - musical, onde ele ficou desorientado quando comecei a explicar sobre os diversos estilos de música extrema dos quais eu gostava, e ele nunca tinha ouvido falar. Ele ainda me contava sobre seus planos de viagem pelo mundo, e que estava juntando grande parte do dinheiro que ganhava como professor na "Bosque" para passar uma temporada na Europa ou nos Estados Unidos.

Quem também lecionava Literatura e Língua Portuguesa era o Antônio, que dava aulas para turmas de quinta à oitava série, hoje sexto ao nono ano. Ao acompanhar uma de suas aulas, notei o ótimo relacionamento que ele tinha com os alunos e alunas, e o grande respeito dos(as) jovens enquanto os professores e professoras davam suas aulas. Reparei essa situação não somente na aula do Antônio, mas também ao acompanhar as turmas do Maurício e do Anderson.

No entanto, especificamente a aula que acompanhei do Antônio era a primeira da manhã, e a classe estava bem sonolenta, depois de um longo mês de férias. E aí eram necessárias algumas 
chacoalhadas: "Por favor queridos, acordem, não me envergonhem na frente do Rodrigo, senão ele irá falar mal de nós lá no sul..."

Após ter distribuído alguns livros à turma, ele pedia para que os alunos e alunas escolhessem um texto, lessem em voz alta e depois fizessem para a classe uma reflexão sobre o que haviam entendido da leitura. Só que, naquele momento da manhã, nem oito horas ainda, ainda era difícil qualquer exercício.

Perguntei ao Antônio, após a aula, se a minha presença na classe estava inibindo a participação dos jovens, ou se era uma questão de timidez: "Nem uma coisa, nem outra, Rodrigo. O problema deles é a grande preguiça de pensar". Disse-lhe, naquele momento, que esta questão não era exclusiva de seus e suas estudantes, nem um problema específico do Amapá, mas que também encarava a mesma situação entre meus alunos e alunas.

O Antônio dizia que, como professor, sentia a obrigação de incentivar os alunos e alunas à leitura. Para isso, afirmava que talvez tivesse que ficar mais tempo dentro de sala de aula, e não trabalhar tanto ao ar livre, como sugeria a coordenação da escola. Por considerar a Língua Portuguesa mais especificamente teórica do que as outras nas quais era possível um contato maior com o ambiente natural, como Geografia, Ciência e Artes, sair muito com os(as) estudantes poderia dispersar ainda mais sua atenção.

\section{Saudades das famílias}

Sobre a preguiça de pensar, também reclamava a Mirela. Professora de Sociologia, Psicologia e História da Educação para estudantes do magistério da Escola Bosque, ela estava com um machucado muito grande em uma das pernas, pois durante o Bailique Verão havia caído em um buraco entre as madeiras da passarela. Quando caminhava com o Leonardo pelo Hotel Escola Bosque, percebi que esse era um risco real.

Nas aulas que pude presenciar, ela discutia Vygotsky e Piaget sobre o desenvolvimento cognitivo da criança, e relatava aos seus alunos e alunas sobre sua trajetória de vida. Por ter tido a primeira filha aos dezessete anos, não pôde prestar uma atenção mais minuciosa às suas fases de desenvolvimento.

Brincava com a turma dizendo que desejava ter outro filho para "usar de cobaia" em suas observações. Durante nossa breve conversa, me contou Mirela, depois da aula, que a turma da 
noite era ainda mais participativa que a turma da manhã - que já era muito entusiasta e dialógica - e que, frequentemente, se não controlasse o ímpeto das discussões, muitas vezes ficava sem falar devido à empolgação das alunas e alunos.

Mirela havia deixado suas filhas em Belém, e falava muito sobre a saudade que sentia, reclamando demais da distância. Também me dizia que a sua estadia no Bailique seria passageira, e assim que terminasse sua pós-graduação em Psicologia pela Universidade Federal do Amapá, ela se desligaria da Escola Bosque.

Como já haviam me dito o Maurício e o Anderson, a Mirela me contou sobre a relativa decepção que os professores e professoras acabavam tendo ao trabalhar na Escola Bosque, pois os representantes da Secretaria de Educação do Estado apresentavam a escola de uma maneira que não condizia à realidade, tanto em relação à estrutura, quanto aos recursos e às possibilidades de concretizar aquilo que os idealizadores da escola haviam pensado.

Mesma coisa foi me dita pela Maria, professora de Artes. Formada pela Universidade Federal do Amapá, estava adiantando as suas aulas, pois teria que retornar e ficar uns dias a mais em Macapá, pois havia acabado de se formar e queria participar de todos os eventos da formatura.

Durante uma de suas janelas de aula, Maria me relatou sobre os inúmeros problemas que teve ao chegar ao Bailique, desde a alimentação - que em alguns dias consistiu unicamente de arroz, feijão e macarrão - até a possibilidade de não ficar no alojamento da escola e, portanto, não contar com a ajuda dos professores no caso de alguma emergência.

Estar no alojamento, apesar da falta de privacidade, era essencial em situações em que houvesse algum problema grave, como o caso contado por ela - e confirmado pelos colegas - de um professor que havia tido convulsões e febre. Se não estivesse no alojamento e contasse com o apoio dos colegas, algo pior poderia ter acontecido.

Também contava que, ao chegar à escola, teve que "bater o pé" e insistir para que suas aulas não fossem somente práticas - como havia recomendado a coordenação - mas que também houvesse o estudo da teoria da Arte e sua relação com as outras áreas do conhecimento. Comemorava que o seu pedido havia sido aceito.

E ela exercia essas aulas teóricas com afinco, preocupada com a construção do conhecimento sobre artes pelos alunos. Na aula em que presenciei, ela fez uma longa explanação sobre o folclore, e as diversas dimensões da história das artes. No entanto, sua aula não durou 
muito tempo, pois os alunos e alunas, que em grande parte eram adultos que trabalhavam durante o dia, quiseram ir embora mais cedo, devido ao receio da energia elétrica acabar antes que chegassem a suas casas.

Tanto a Maria quanto a Mirela, reclamavam que, devido às aulas do período noturno se encerrarem dez e meia da noite, e a energia elétrica acabar as onze - devido aos geradores movidos a óleo diesel - não era possível, durante à noite, nem estudar, e muito menos preparar as aulas para o dia seguinte. Somente quando havia jogos de futebol de times grandes de São Paulo, do Rio de Janeiro ou do Pará, a luz acabava próximo à meia-noite.

Assim como a Mirela, a Maria era mãe de duas meninas, deixadas em Macapá. Ela ainda me contava da grande vitória que foi conseguir se formar, pois como o curso de Artes, naquele momento, não tinha boa estrutura na Universidade Federal do Amapá, havia situações nas quais os próprios estudantes tinham que procurar professores para lhes dar aulas. Criticou longamente também o Governo Federal e o então presidente Fernando Henrique Cardoso, o qual, segundo ela, havia dado uma declaração sobre a necessidade de retirar o ensino de Artes das escolas públicas. Pergunto-me o que estaria pensando Maria, hoje, sobre a mudança do Ensino Médio proposta pelo Governo Temer...

Assim como a Maria, a professora Andressa era recém-chegada à Escola Bosque do Bailique, estando ali há pouco mais de dois meses, e que ainda estava criando vínculos com os alunos e alunas, além de estar se familiarizando com a comunidade. Professora de Língua Portuguesa, dizia que apesar das saudades da família e da distância do Bailique em relação à Macapá, era bem melhor estar trabalhando ali do que em alguma escola particular na região urbana.

Antes de ir ao Bailique, a Andressa havia lecionado em uma grande rede de ensino nacional que tem uma unidade na cidade de Macapá. Ela afirmava que os alunos e alunas do colégio, por serem filhos(as) da elite macapaense, se julgavam no direito de maltratar e desrespeitar professores(as) e funcionários(as) do colégio. No entanto, apesar de toda a pompa da instituição, sua saída foi justamente por falta de pagamento.

$\mathrm{Na}$ "Bosque" ela não obrigava ninguém a ficar em sala de aula, mas pedia para os que ficassem não perturbasse e/ou atrapalhassem a aula, e que também participassem ativamente das suas discussões e propostas. Dizia-me a Andressa que conseguia manter as salas cheias devido às diversas atividades que promovia, entre as quais estavam a criação de histórias, fábulas, contos, 
narrações, montagem de jornal estudantil, e até a descrição escrita e desenhada dos professores e professoras da escola. Descrições que, obviamente, não mostrava a ninguém e guardava a sete chaves dos colegas de trabalho, apesar dos inúmeros e encarecidos pedidos.

Diferenciava a turma da manhã com a turma da tarde, dizendo que os jovens vespertinos eram mais ativos, e destacava, falando sobre mim, que a vinda de visitantes à escola despertava, muitas vezes, mais a atenção dos alunos e alunas, do que dos próprios viajantes. Quem era a pessoa, de onde vinha, e quais eram seus interesses na escola.

\section{E onde estava a chave? ...}

Outro professor que era recém-chegado à Escola Bosque era o Sérgio. Ele havia acabado de se formar em História pela Universidade Federal do Amapá, e também estava há pouco mais de dois meses na escola. No barco, conversamos longamente sobre a importância de pensadores brasileiros como Milton Santos, Darcy Ribeiro e Sérgio Buarque de Holanda, e também sobre as diferenças entre uma universidade pública federal no norte do país e uma universidade particular tradicional no interior do estado de São Paulo.

Contava-me orgulhosamente que, além de ter acabado de concluir sua monografia, havia ganhado uma bolsa por outro trabalho que estava desenvolvendo a respeito da era Vargas e sua repercussão no norte do Brasil, e que pretendia continuar essa temática em uma futura pósgraduação.

Sua docência no Bailique estava sendo a primeira experiência na educação, e além de superar a falta de maior prática pedagógica, ainda estava criando vínculos com os alunos e alunas, e também com a comunidade. Seu estilo era bastante formal, e me dizia que, para ensinar História, era necessária essa formalidade e também um amplo domínio do assunto a ser tratado. Mostrava grande seriedade ao trabalhar com o absolutismo e as monarquias europeias, tentando constantemente fazer uma ligação direta com a história brasileira e a formação do país.

Mas assim como na aula do Antônio, os alunos e alunas não estavam muito animados(as) e participativos(as), devido, também, ao horário do início das atividades. Ainda era muito cedo, e o Sérgio tentava constantemente animar a turma, fazendo uns breves intervalos para contar alguma situação engraçada e acordar os jovens. Também comentava após a aula que um grande 
problema das classes era a preguiça de pensar. No entanto, como forma de quebrar o gelo e as angústias do Sérgio, disse-lhe que, às sete da manhã, até eu não estava muito disposto a pensar.

Durante a semana em que fiquei no Bailique, fiquei acampado no alojamento da Escola Bosque. Além dos professores dos quais já escrevi, havia alguns ainda que não haviam chegado, e também alguns outros com os quais não tive oportunidade de conversar ou acompanhar as aulas, devido às muitas atividades durante aquele período. Entre eles estava o casal Marcos e Flávia (ele era professor de Literatura e ela de Educação Infantil), a Talita (que havia trocado o trabalho de carcereira para dar aulas de Matemática), o Sanchez e a Juliane (ambos de Ciências) e a Rosa (também de Matemática).

Um professor que estava praticamente morando no alojamento era o Alcir, cujo pequeno espaço era tomado de livros e da sua ampla coleção de cartões telefônicos. Vivendo da aposentadoria que ganhava do Governo de Pernambuco, mandava todo o dinheiro que recebia como professor de Geografia na Escola Bosque, para o filho que cursava medicina na Bolívia.

O Alcir já estava lá quando chegamos e teve, assim como os outros homens, que dividir o alojamento coletivo com as mulheres na noite de nossa chegada. $\mathrm{O}$ alojamento feminino estava trancado, e ninguém na escola sabia onde estava a chave. Todos tiveram que se apertar no alojamento masculino. Para minha sorte, como muitos professores não haviam chegado, sobrou uma rede para mim, na qual eu fiquei todos os dias de minha estadia. A busca da chave se tornou uma verdadeira caça ao tesouro, mas ela foi encontrada somente no dia seguinte, quando as merendeiras abriam a cozinha e a encontraram.

\section{De alojamentos, justiça e esquecimento}

Compartilhar o aperto em um alojamento coletivo talvez fosse o menor dos problemas comparado à obrigatoriedade de ficarem vinte e cinco dias por mês em um rincão tão isolado quanto o Bailique. Apesar de telefones públicos disponíveis, sua sonoridade era péssima, e o custo da ligação era muito caro. Não havia celulares largamente disponíveis ainda, e a internet custava a funcionar. Além disso, em qualquer situação de emergência, a viagem até Macapá era muito longa, e os barcos saíam no máximo três vezes por dia. Portanto, esses professores e professoras acabavam cuidando um do outro como se fosse uma grande família. 
Grandes famílias que eram os Amanajás e os Barbosas, as maiores do Bailique, cujas rixas de décadas, largamente explicadas pela Daniela, envolviam brigas corporais, mortes, sabotagens e uma falta de comunicação radical entre os membros das famílias. No entanto, essas famílias estavam cada vez mais se descaracterizando e perdendo sua hegemonia, devido ao êxodo de pessoas do Bailique rumo à Macapá, e a chegada de novos moradores.

À noite, quando não se reuniam no bloco administrativo para organizar seus trabalhos, projetos para escola, ou simplesmente assistir as novelas e os telejornais. Os solteiros e as solteiras iam aos forrós e bailes bregas que ocorriam, geralmente, na Vila Macedônia, que se localiza na ilha do Brigue, bem em frente à Vila Progresso e à Escola Bosque.

Quando eu estive lá, boa parte das professoras e professoras me disseram que faziam questão de ficar conversando comigo, assim como faziam com outros estudantes e professores que não eram do Amapá e/ou da região norte, pois queriam saber tanto as notícias do mundo afora e a dinâmica enlouquecida do Centro-Sul do país, como adoravam contar sobre suas histórias de vida, suas famílias, suas ilusões, desilusões e esperança de futuros melhores. E, de alguma forma, queriam que aquela condição em que se encontravam fosse conhecida por mais pessoas.

Faziam-me companhia enquanto eu observava as marés da foz do Amazonas destruírem os barrancos nas margens dos rios em fins de tarde magníficos (houve somente um dia de chuva intensa), como muitos que presenciei e diversas vezes me roubavam a atenção, enquanto assistia a reunião entre o corpo docente para discutir a divisão da alimentação, ou enquanto registrava minhas conversas na pequena doca em frente à escola, entre um pulo e outro dos botos cor-derosa.

Durante os anos em que a Escola Bosque do Bailique era enaltecida e retratada como uma possível potencializadora da necessária mudança da educação brasileira, os professores e professoras não recebiam o devido protagonismo, tanto nas belas reportagens da TV Cultura, como da extinta revista Caminhos da Terra (CALDAS, 2001), da Isto É (KLINKE, 1998), da Nova Escola (BENCINI, 1998), da Folha de S. Paulo (AVANCINI, 1998) e do Estado de S. Paulo (MURPHY, 1998). Caía sobre eles e elas, na maior parte, a responsabilidade não somente de manter e fortalecer o projeto pedagógico da escola em si, mas tocar adiante a proposta do PDSA na região do Bailique, a partir dos preceitos de uma educação ambiental que levava em 
consideração o saber local e as possibilidades de fortalecimento comunitário a partir das potencialidades ecológicas e econômicas da região.

Vale lembrar também que a experiência da Escola Bosque do Bailique foi completamente obliterada e esquecida durante o processo de criação do material de referência, das políticas e programas nacionais de educação ambiental nos governos Lula, entre 2003 e 2010. Nenhuma referência ou citação sobre o trabalho no Bailique é encontrado em nenhum dos documentos produzidos nesse período, expondo ainda mais a brutal tentativa de apagamento e a falta plena de reconhecimento por aquela experiência.

Esse texto que escrevo, portanto, não é somente para enaltecer o protagonismo dessas professoras e professores, deixado em segundo plano, inclusive, pelo Governo do Estado do Amapá, na época, como relatado em muitas das falas que registrei aqui. Mas os registros que trago também são para fazer vir à tona, nem que seja uma última vez, os fragmentos da esperança sobre uma experiência que se está quase que perdida devido à corrupção, ineficiência e incipiência dos gestores da educação brasileira. Mas que também se mantém, ainda, nem que seja infinitesalmente, como potencializadora de uma virtual transformação radical da educação brasileira, e das relações entre o meio ambiente e a educação.

\section{Referências}

AMAPÁ. Centro de Amapaense de Atividades Culturais, Econômicas e Sociais - CAACES. Bailique: desenvolvimento sustentável no Delta do Amazonas. Macapá: Governo do Estado do Amapá: Unicef, 2000.

AMAPÁ. Governo do Estado. Bases para o desenvolvimento sustentável: coletânea de textos. Macapá: Centro de Formação e Desenvolvimento de Recursos Humanos - CEFORH, 1999.

AMAPÁ. Governo do Estado. Secretária de Estado da Educação. Centro de referência de Ilha de Santana. Macapá: SEE, 1997a. Série projeto escola Bosque do Amapá, n. 1.

AMAPÁ. Governo do Estado. Secretária de Estado da Educação. O método sócio-ambiental. Macapá: SEE, 1997b. Série projeto escola Bosque do Amapá, n. 2.

AMAPÁ. Governo do Estado. Secretária de Estado da Educação. Projeto de socialização. Macapá: SEE, 1997c. Série projeto escola Bosque do Amapá, n. 3.

AMAPÁ. Governo do Estado. Secretária de Estado da Educação. Aspectos pedagógicos. Macapá: SEE, 1997d. Série projeto escola Bosque do Amapá, n. 4.

AMAPÁ. Governo do Estado. Secretária de Estado da Educação. Módulo regional do Bailique. Macapá: SEE, 1997e. Série Projeto Escola Bosque do Amapá, n. 5. 
AMAPÁ. Governo do Estado. Secretária de Estado da Educação. Aspectos sócio-econômicos-ambientais da região do Bailique. Macapá: SEE, 1997f. Série projeto escola Bosque do Amapá, n. 6.

AMAPÁ. Governo do Estado. Secretária de Estado da Educação. Módulo regional do Bailique: memorial do projeto. Macapá: SEE, 1997g. Série projeto escola Bosque do Amapá, n. 7.

AVANCINI, Marta. Escola na floresta propõe o uso do meio ambiente para alfabetizar. Folha de S. Paulo, São Paulo, 11 jun. 1998. p. 6.

BENCINI, Roberta. A escola que nasceu da mata. Revista Nova Escola, São Paulo, v. 13, n. 116. p. 3639, out. 1998.

CALDAS, Sérgio Túlio. O Brasil em estado bruto. Os Caminhos da Terra, São Paulo, n. 110, jun. 2001.

KLINKE, Angela. Estado Alternativo. Isto É, São Paulo, 24 jun. 1998.

LEONELLI, Domingos. Uma sustentável revolução na floresta. São Paulo: Viramundo, 2000.

MENEGON, Vera Mencoff. Porque jogar conversa fora? Pesquisando no cotidiano. In: SPINK, Mary Jane Paris (Org.). Práticas discursivas e produção de sentido no cotidiano: aproximações teóricas e metodológicas. São Paulo: Cortez, 1999.

MOULIN, Nilson (Org.). Amapá: um norte para o Brasil: diálogo com o governador João Alberto Capiberibe. São Paulo: Cortez, 2000.

MURPHY, Priscila. Amapá adota desenvolvimento sustentável. O Estado de S. Paulo, São Paulo, 20 jun. 1998. p. A13.

RATIER, Rodrigo; SALLA, Fernanda; SEMIS, Laís. A escola Bosque do Amapá poderia ter mudado a educação: no abandono de um projeto-modelo, a síntese de um ensino que agoniza com a descontinuidade administrativa. Revista Nova Escola, São Paulo, v. 30, n. 281, p. 52-57, abr. 2015.

REIGOTA, Marcos. Ecologistas. Santa Cruz do Sul: EDUNISC, 1999.

REIGOTA, Marcos. Sou neto do Tomé. In: KUENZER, Acácia Zeneita et al. (Org.). Cultura, linguagem e subjetividade no ensinar e aprender. São Paulo: DP\&A, 2000.

SPINK, Mary Jane Paris (Org.). Práticas discursivas e produção de sentido no cotidiano: aproximações teóricas e metodológicas. São Paulo: Cortez, 1999.

SPINK, Peter Kevin. O pesquisador conversador no cotidiano. Psicologia \& Sociedade, Porto Alegre, v. 20, edição especial, p. 70-77, 2008.

Rodrigo Barchi - Universidade de Sorocaba - Uniso. Sorocaba | SP

| Brasil. Contato: rodrigo.barchi@prof.uniso.br 